\title{
Structure and Properties of Zr-Mo-Si-B-(N) Hard Coatings Obtained by d.c. Magnetron Sputtering of $\mathrm{ZrB}_{2}-\mathrm{MoSi}_{2}$ Target
}

\author{
Philipp Kiryukhantsev-Korneev ${ }^{1, *(\mathbb{D}}$, Alina Sytchenko ${ }^{1}$, Yuriy Pogozhev ${ }^{1}$, Stepan Vorotilo ${ }^{1}$, Anton Orekhov ${ }^{1,2}{ }^{(0)}$, \\ Pavel Loginov ${ }^{1}$ (i) and Evgeny Levashov ${ }^{1}$ (i) \\ 1 Scientific-Educational Center of SHS, National University of Science and Technology "MISiS", \\ 119049 Moscow, Russia; alina-sytchenko@yandex.ru (A.S.); yspogozhev@mail.ru (Y.P.); \\ stepan.vorotylo@gmail.com (S.V.); orekhov.anton@gmail.com (A.O.); pavel.loginov.misis@list.ru (P.L.); \\ levashov@shs.misis.ru (E.L.) \\ 2 Laboratory of Electron Diffraction, Federal Scientific Research Centre "Crystallography and Photonics", \\ Russian Academy of Sciences, Leninsky Prospect 59, 119333 Moscow, Russia \\ * Correspondence: kiruhancev-korneev@yandex.ru; Tel.: +7-(495)-638-46-59
}

Citation: Kiryukhantsev-Korneev, P. Sytchenko, A.; Pogozhev, Y.; Vorotilo, S.; Orekhov, A.; Loginov, P.; Levashov, E. Structure and Properties of Zr-Mo-Si-B-(N) Hard Coatings Obtained by d.c. Magnetron Sputtering of $\mathrm{ZrB}_{2}-\mathrm{MoSi}_{2}$ Target. Materials 2021, 14, 1932. https:// doi.org/10.3390/ma14081932

\section{Academic Editors:}

Gueorgui Gueorguiev and Albert Verdaguer

Received: 19 February 2021

Accepted: 8 April 2021

Published: 13 April 2021

Publisher's Note: MDPI stays neutral with regard to jurisdictional claims in published maps and institutional affiliations.

Copyright: (c) 2021 by the authors. Licensee MDPI, Basel, Switzerland. This article is an open access article distributed under the terms and conditions of the Creative Commons Attribution (CC BY) license (https:/ / creativecommons.org/licenses/by/ $4.0 /)$.

\begin{abstract}
Coatings in a $\mathrm{Zr}-\mathrm{Mo}-\mathrm{Si}-\mathrm{B}-\mathrm{N}$ system were deposited by the magnetron sputtering of $\mathrm{ZrB}_{2}$ $\mathrm{MoSi}_{2}$ targets in argon and nitrogen. The structure of the coatings was investigated using scanning electron microscopy, X-ray diffraction, energy-dispersive spectroscopy, and glow-discharge optical emission spectroscopy. Mechanical and tribological properties were measured using nanoindentation and pin-on-disc testing. Oxidation resistance and oxidation kinetics were estimated via annealing in air at $1000-1500{ }^{\circ} \mathrm{C}$ and precision weight measurements. We found that the coatings deposited in Ar demonstrate a superior combination of properties, including hardness of $36 \mathrm{GPa}$, elastic recovery of $84 \%$, a friction coefficient of 0.6 , and oxidation resistance at temperatures up to $1200{ }^{\circ} \mathrm{C}$. High oxidation resistance is realized due to the formation of the protective $\left(\mathrm{SiO}_{2}+\mathrm{ZrO}_{2}\right) / \mathrm{SiO}_{2}$ oxide layer, which inhibits the diffusion of oxygen into the coating.
\end{abstract}

Keywords: magnetron sputtering; coating; $\mathrm{ZrB}_{2} ; \mathrm{MoSi}_{2} ; \mathrm{Zr}-\mathrm{Mo}-\mathrm{Si}-\mathrm{B}-(\mathrm{N})$; structure; mechanical and tribological properties; oxidation resistance

\section{Introduction}

Zirconium diboride is promising in multipurpose protective coatings for high-temperature units in aviation and space technology, the power engineering industry, metal-formed tools, cutting and machining tools, molds, etc., due to its extremely high melting temperature $\left(3245^{\circ} \mathrm{C}\right)$, high thermal conductivity $\left(57.9 \mathrm{Wt} \cdot \mathrm{m}^{-1} \cdot \mathrm{K}^{-1}\right)$, low coefficient of thermal expansion $\left(5.9 \times 10^{-6}{ }^{\circ} \mathrm{C}^{-1}\right)$ [1], high oxidation resistance (up to $2000{ }^{\circ} \mathrm{C}$ ) [2], high hardness (22 GPa), and wear resistance [3]. The oxidation resistance of protective coatings can be enhanced via alloying by Si [4-6] or the introduction of silicon-containing phases, such as $\mathrm{SiC}, \mathrm{SiBC}$, and $\mathrm{TaSi}_{2}$ [7-9]. Silicon improves the oxidation resistance due to the formation of borosilicate glass on the surface of the material upon oxidation. This glass layer efficiently retards the diffusion of oxygen $[10,11]$. One of the most widely used high-temperature coatings is $\mathrm{ZrB}_{2}-\mathrm{SiC}$ [12-14], which demonstrates high protective properties and oxidation resistance up to $1500{ }^{\circ} \mathrm{C}$. Over the last five years, there has been a considerable increase of interest toward $\mathrm{ZrB}_{2}-\mathrm{MoSi}_{2}$ coatings for the protection of carbon-carbon $(\mathrm{C} / \mathrm{C})$ and carbon-ceramic (C/SiC) composites from oxidation [15-19]. A comparison of $\mathrm{ZrB}_{2}-\mathrm{SiC}$ and $\mathrm{ZrB}_{2}-\mathrm{MoSi}_{2}$ coatings demonstrated that a $\mathrm{MoSi}_{2}$-alloyed specimen possessed a denser structure and higher oxidation resistance [20]. References [21,22] analyzed the effect of the introduction of $\mathrm{MoSi}_{2}$ and $\mathrm{TaSi}_{2}$ in $\mathrm{ZrB}_{2}$-based coatings. The $\mathrm{ZrB}_{2}-\mathrm{MoSi}_{2}$ coating experienced almost no oxidation at $1500{ }^{\circ} \mathrm{C}$ due to the formation of a dense oxide layer, whereas the $\mathrm{ZrB}_{2}-\mathrm{TaSi}_{2}$ coating formed a porous oxide layer that offered no protection against the influx of oxygen. In parallel, several dense ceramics and coatings are being developed based on MoSiB alloyed by various elements (Y, Al, Fe, Zr) [23-26]. 
$\mathrm{ZrB}_{2}-\mathrm{MoSi}_{2}$ and Mo-Si-B-Zr coatings are usually deposited using diffusion saturation [26,27], plasma deposition [21,28], flame spraying [19], and impregnation [29]. PVD and CVD are arguably the most interesting methods for the deposition of $\mathrm{ZrB}_{2}$ $\mathrm{MoSi}_{2}$ coatings from both a scientific and technological point of view, yet no such studies can be currently found in the literature. The closest analogs are coatings $\mathrm{Zr}-\mathrm{Si}-\mathrm{B}$ and Mo-Si$B$, which were previously deposited by magnetron sputtering [5,8,25,30-32]. It should be noted that the properties of the coatings (in particular, tribological performance) can be greatly enhanced by the introduction of nitrogen into the coating via the sputtering in the nitrogen atmosphere [33,34].

This work aimed to deposit Zr-Mo-Si-B-(N) coatings via magnetron sputtering and investigate their structure, oxidation resistance, and mechanical and tribological properties.

\section{Materials and Methods}

Sputtering targets with a diameter of $120 \mathrm{~mm}$ and thickness of $5 \mathrm{~mm}$ were produced by combustion synthesis. The phase composition of the targets was investigated by XRD using a DRON-4 installation (RPE "Burevestnik", St. Petersburg, Russia). A scanning electron microscope (SEM) S3400 (Hitachi, Tokyo, Japan) with an EDS add-on Noran 7 Thermo was used for the microstructural investigations. XRD analysis revealed that the ceramic target contained $89.5 \% \mathrm{~h}-\mathrm{ZrB}_{2}$ with lattice parameters $\mathrm{a}=0.3155 \mathrm{~nm}, \mathrm{c}=0.3507 \mathrm{~nm}$, and $10.5 \% \mathrm{t}$ $\mathrm{MoSi}_{2}(\mathrm{a}=0.3209 \mathrm{~nm}, \mathrm{c}=0.7864 \mathrm{~nm})$. Structural components could be easily recognized on the EDS maps, whereas the SEM images did not reveal clear phase boundaries (Figure 1).

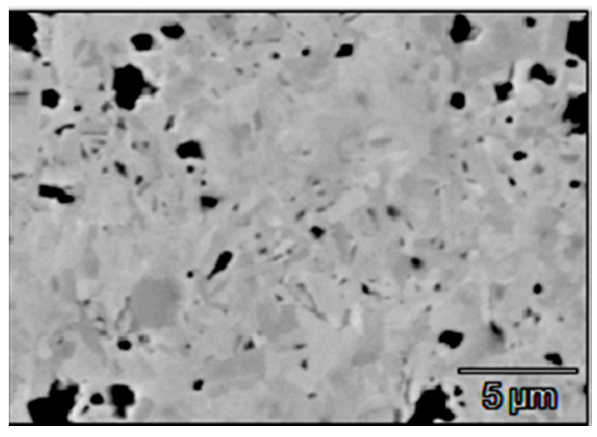

(a)

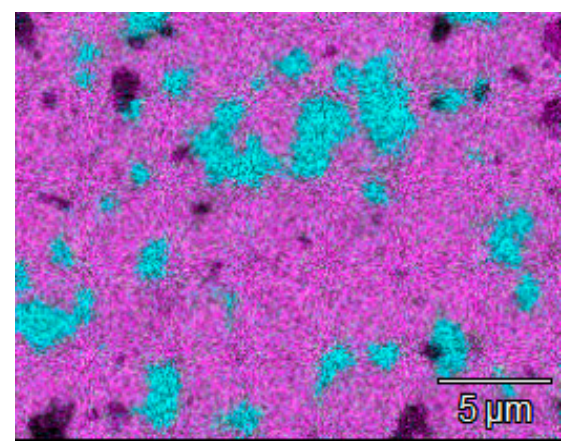

(b)

Figure 1. SEM image (a) and EDS map (b) of the cathode target (violet-Zr, blue- Si).

The zirconium diboride matrix contained 1-5 $\mu \mathrm{m}$ inclusions of molybdenum silicide. The ceramic target was characterized by hardness of $19 \mathrm{GPa}$ and fracture toughness of 6.69 $\mathrm{MPa} \times \mathrm{m}^{1 / 2}$.

The magnetron sputtering of the ceramic targets was performed in a direct current mode using a UVN-2M apparatus, described in detail elsewhere [35]. This apparatus employs a Pinnacle Plus $5 \times 5$ power supply (Advanced Energy) equipped with an arcextinguishing system. The current and voltages were $2 \mathrm{~A}$ and $400-500 \mathrm{~V}$, and the power was $1 \mathrm{~kW}$. The target sputtering was performed in pure $\mathrm{Ar}(99.9995 \%)$ or $\mathrm{N}_{2}(99.999 \%)$ at a pressure of $0.1-0.2 \mathrm{~Pa}$. The temperature of the substrate during deposition was $\sim 350{ }^{\circ} \mathrm{C}$. The bias voltage was not applied to the substrate. The substrate-target distance was about $80 \mathrm{~mm}$. Plates made of VOK-100-1-grade alumina were used as the substrates. Before deposition, the substrates were cleaned by $\mathrm{Ar}^{+}$ions with a $1.5-2 \mathrm{keV}$ energy for $20 \mathrm{~min}$ at a pressure of $0.08 \mathrm{~Pa}$ using a slit-type ion source. The deposition duration was $40 \mathrm{~min}$. To test the oxidation resistance of the coatings, they were annealed at $1000{ }^{\circ} \mathrm{C}$ for $1 \mathrm{~h}$ in the air using a SNOL-7.2/1200 muffle furnace. The elemental profiles and chemical composition of the coatings were analyzed using glow-discharge optical emission spectroscope (GDOES) PROFILER-2 (Horiba Jobin Yvon, Longjumeau, France) [36]. The set of standards from Horiba JY and additional bulk and film standards including TiN, TiCaCOPN, ZrN, TiB, and $\mathrm{CrN}$ were used for calibration. The cross-section fractures of the coatings were investi- 
gated using SEM Hitachi S4800 in a secondary electron emission regime at the accelerating voltage of 20-30 kV. The XRD analysis of the as-deposited and annealed coatings was performed on a Bruker D2 Phaser apparatus using the Bragg-Brentano configuration and $\mathrm{CuK} \alpha$ radiation. Mechanical properties of the coatings were tested using the precision Nano-Hardness Tester (CSM Instruments, Peseux, Switzerland). The penetration depth at a $4 \mathrm{mN}$ load did not exceed $10 \%$ of the coating's thickness. The tribological measurements were performed at a Tribometer automated friction machine (CSM Instruments) using a pin-on-disc scheme with an alumina ball counterbody (diameter of $6 \mathrm{~mm}$ ) at normal loads of 1 and $5 \mathrm{~N}$. The wear tracks were analyzed using a Wyko-1100NT optical profilometer (Plainview, NY, USA) which was described in detail elsewhere [37].

\section{Results and Discussion}

According to the GDOES data, all the elements were distributed homogeneously across the coating's thickness (Figure 2).

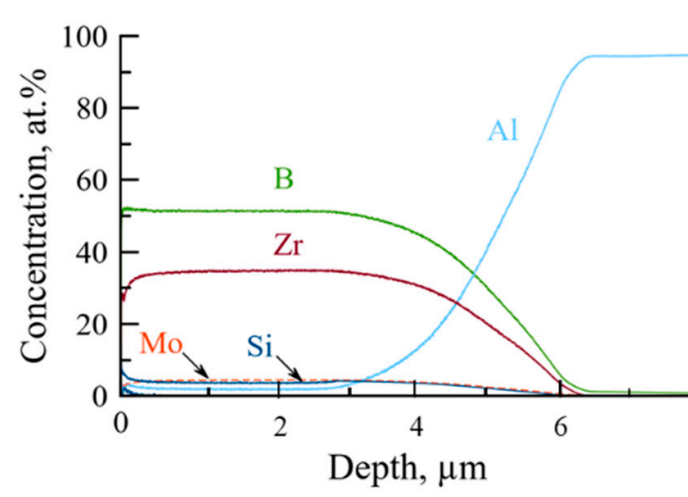

(a)

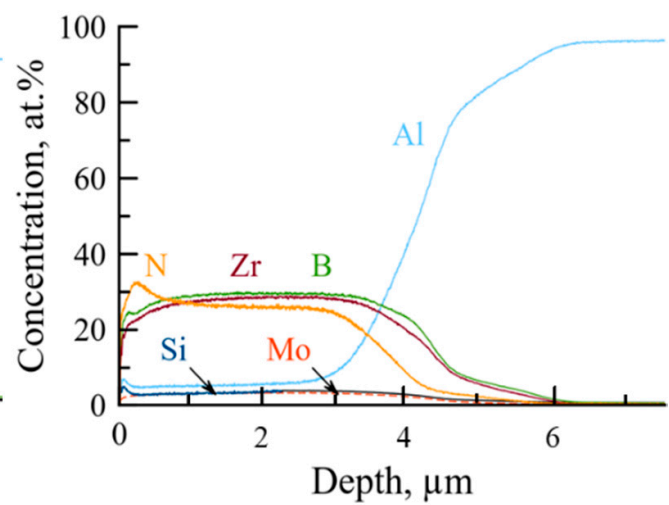

(b)

Figure 2. Elemental profiles of Coatings $1 \mathrm{~A}(\mathbf{a})$ and $2 \mathrm{~N}(\mathbf{b})$.

Depth-averaged elemental concentrations are provided in Table 1.

Table 1. Composition and mechanical properties of the coatings.

\begin{tabular}{|c|c|c|c|c|c|c|c|c|c|c|c|c|}
\hline \multirow{2}{*}{ № } & \multirow{2}{*}{$\begin{array}{c}\text { Deposition } \\
\text { Medium }\end{array}$} & \multicolumn{5}{|c|}{ Composition, at. $\%$} & \multirow{2}{*}{$\mathrm{H}, \mathrm{GPa}$} & \multirow{2}{*}{ E, GPa } & \multirow{2}{*}{$\mathrm{H} / \mathrm{E}$} & \multirow{2}{*}{$\mathrm{H}^{3} / \mathrm{E}^{2}, \mathrm{GPa}$} & \multirow{2}{*}{$\mathrm{W}, \%$} & \multirow{2}{*}{$\mathrm{Vw}, \mathrm{Mm}^{3} /(\mathrm{Nm})$} \\
\hline & & $\mathrm{Zr}$ & Mo & $\mathrm{Si}$ & B & $\mathbf{N}$ & & & & & & \\
\hline $1 \mathrm{~A}$ & $\mathrm{Ar}$ & 37 & 4 & 4 & 55 & 0 & 36 & 415 & 0.087 & 0.271 & 84 & $4.2 \times 10^{-7}$ \\
\hline $2 \mathrm{~N}$ & $\mathrm{~N}_{2}$ & 31 & 3 & 5 & 32 & 29 & 14 & 160 & 0.088 & 0.107 & 64 & - \\
\hline
\end{tabular}

Coating 1A deposited in argon was characterized by a high concentration of boron (55 at.\%) and zirconium (37 at.\%), suggesting that the zirconium diboride was the main structural constituent of the coating. Additionally, the coating contained 4 at.\% of $\mathrm{Si}$ and Mo. Coating $2 \mathrm{~N}$, deposited in $\mathrm{N}_{2}$, contained $\mathrm{Zr}, \mathrm{B}$, and $\mathrm{N}$ in approximately equal proportions ( 30 at.\%), 3 at. $\%$ Mo and 5 at. $\%$ Si. The content of admixtures was relatively low at 1.2 at. $\% \mathrm{O}$ and 1.7 at. $\% \mathrm{C}$ for the coating deposited in nitrogen and 0.04 at. $\% \mathrm{O}$ and 0.22 at. $\% \mathrm{C}$ for the coating deposited in Ar.

The chemical composition of the coatings was also measured using EDS in conjunction with the SEM investigation of the coating's fractures. It should be noted that the EDS data on the content of light elements (especially boron) were likely erroneous. EDS data for Coating $1 \mathrm{~A}$ suggests the $30-31$ at.\% boron content, which is more than 1.5 times below the GDOES data. For Coating $2 \mathrm{~N}$, the EDS data for boron content were $0-8$ at. $\%$, whereas the nitrogen content was as high as 70 at. $\%$, which is unlikely for the condensed materials. Therefore, the GDOES data, in this case, is more credible. 
SEM images of the cross-section fractures of the Coatings $1 \mathrm{~A}$ and $2 \mathrm{~N}$ are provided in Figure 3.

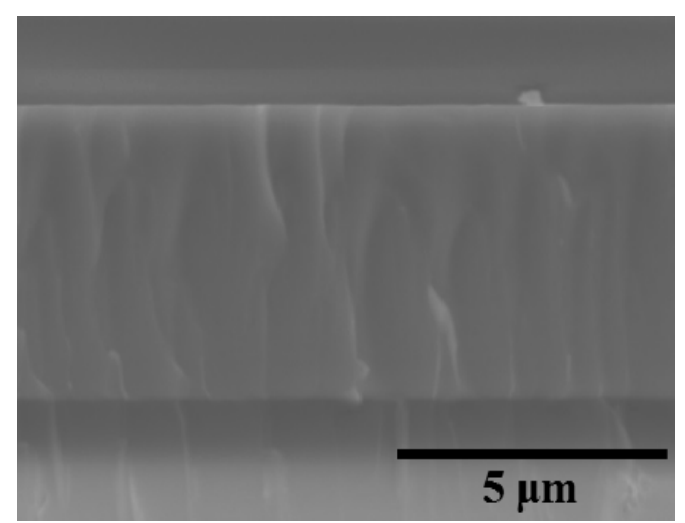

(a)

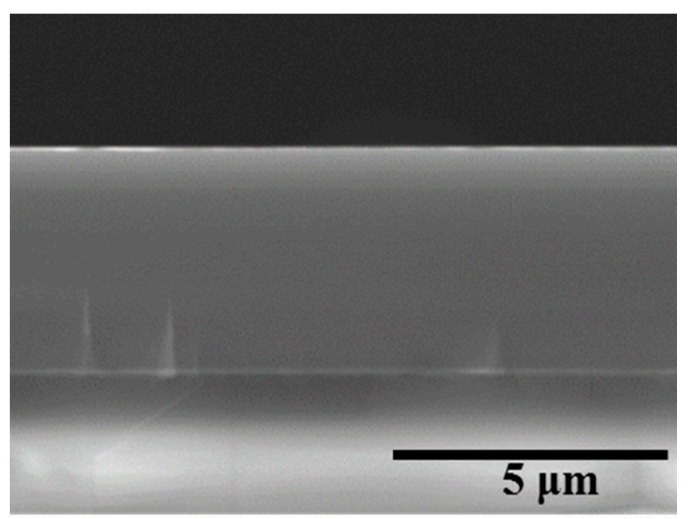

(b)

Figure 3. SEM images of Coatings $1 \mathrm{~A}(\mathbf{a})$ and $2 \mathrm{~N}(\mathbf{b})$.

Both coatings possess a dense structure with no structural defects or columnar grains, which are characteristic of PVD coatings [38-40]. The fracture of Coating 1A conformed to the fracture of the substrate. The fracture of Coating $2 \mathrm{~N}$ was characteristic of the amorphous coatings [41]. The thickness of Coatings $1 \mathrm{~A}$ and $2 \mathrm{~N}$ was estimated from the cross-section fracture images as 5.0 and $3.7 \mu \mathrm{m}$, correspondingly.

The growth rate of the SEM-derived coating was 125 and $93.5 \mathrm{~nm} / \mathrm{min}$ for Coatings $1 \mathrm{~A}$ and $2 \mathrm{~N}$, respectively. The decrease in the coating growth rate upon the transition from argon to nitrogen sputtering atmosphere can be explained by the easier ionization of argon as compared to nitrogen [42,43]. Additionally, the sputtered atoms from the target experience more scattering during their flight to the substrate when a heavier working gas is used. The measurement of the surface roughness via optical profilometry indicated that Coating 1 has the roughness of $\mathrm{Ra}=68 \mathrm{~nm}$, whereas the introduction of nitrogen reduced the surface roughness to $\mathrm{Ra}=12 \mathrm{~nm}$, which is close to $\mathrm{Ra}=10 \mathrm{~nm}$ for the alumina substrate. The decrease in surface roughness with the introduction of nitrogen can be explained by the structural refinement of the coating [44,45].

The XRD patterns of the coatings were recorded at $2 \Theta=10-120^{\circ}$ diapason. Figure 4 contains a pattern fragment $2 \Theta=20-70^{\circ}$, in which the phase reflexes with the highest intensity are located.

Samples $1 \mathrm{~A}$ and $2 \mathrm{~N}$ demonstrated peaks corresponding to the $\mathrm{Al}_{2} \mathrm{O}_{3}$ substrate (JCPDS 10-0173). Coating 1A deposited in Ar contained reflexes (001), (002), (112), and (210) of the hexagonal phase h-ZrB 2 (JCPDS 89-3930). The Scherrer-equation-derived size of h- $\mathrm{ZrB}_{2}$ was $44-48 \mathrm{~nm}$. The lattice parameters of $\mathrm{h}-\mathrm{ZrB}_{2}$ were $\mathrm{a}=0.320 \mathrm{~nm}$ and $\mathrm{c}=0.345 \mathrm{~nm}$, which are slightly different from the JCPDS card $(a=0.3165 \mathrm{~nm}, \mathrm{c}=0.3530 \mathrm{~nm})$. The change in the lattice parameter might be related to the deviation of the $\mathrm{h}-\mathrm{ZrB}_{2}$ phase from the stoichiometry. In the case of Coating $2 \mathrm{~N}$ deposited in $\mathrm{N}_{2}$, the XRD pattern contained a broad reflex at $2 \Theta=30-35^{\circ}$. No other reflexes corresponding to the coating were found. Therefore, the introduction of nitrogen resulted in the amorphization of the coating. Interestingly, the amorphous halo is located near the $2 \Theta v a l u e$, which corresponds to the (111) reflex of the $\mathrm{ZrN}$ phase (JCPDS 89-5269). The increase in the nitrogen concentration resulted in the formation of the nitride bonds $\mathrm{Zr}-\mathrm{N}$, which were more energetically favorable and therefore hampered the formation of $\mathrm{Zr}-\mathrm{B}$ bonds. This result supports the previous works $[46,47]$ which demonstrated that in the Me-Si-B-C-N and Zr-B-C-N among all the possible bonds the Me-N (Me = Ti, Zr, Hf) are the most favorable. The formation of some B-N bonds in the $2 \mathrm{~N}$ coatings is also possible. The location of the main peak of $\mathrm{h}-\mathrm{BN}$ is close to $2 \Theta=27^{\circ}$ (JCPDS 85-1068). 


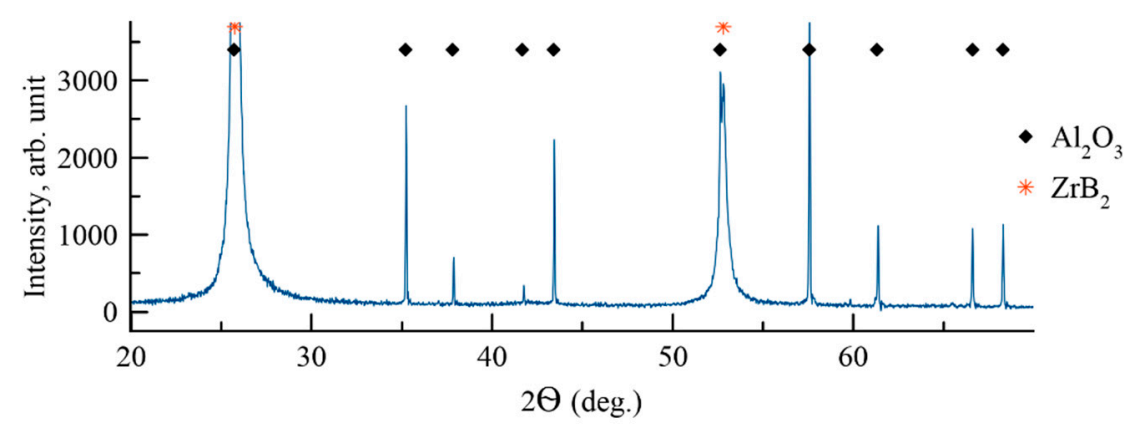

(a)

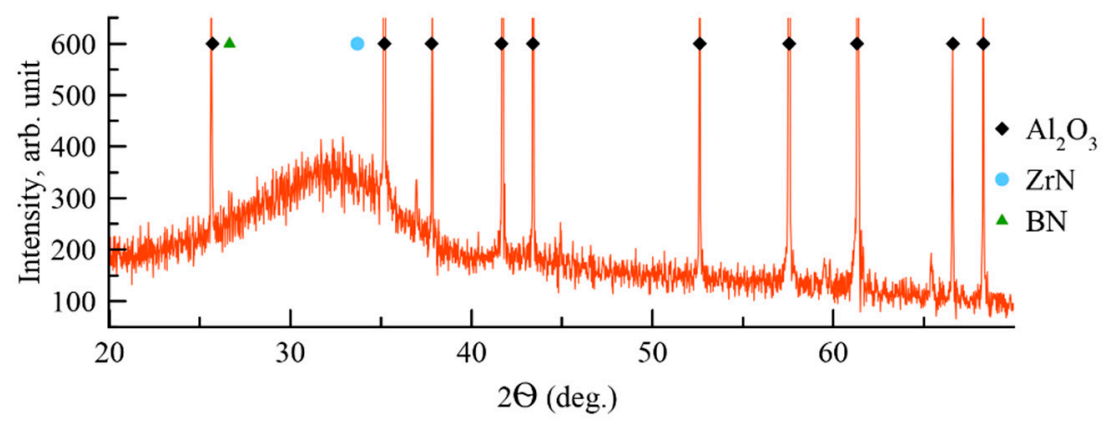

(b)

Figure 4. XRD patterns of Coatings $1 \mathrm{~A}(\mathbf{a})$ and $2 \mathrm{~N}(\mathbf{b})$.

In the case of $2 \mathrm{~N}$ coatings, due to the competitive simultaneous nucleation and growth of the phases, the overall crystalline structure did not form, resulting in the formation of an amorphous coating. A similar effect was reported earlier for Cr-Al-Si-B-(N), Ti-B-Si-N, and Ti-B-C-N coatings [41,48,49].

Figure 5 provides the result of the TEM investigation of the produced coatings.

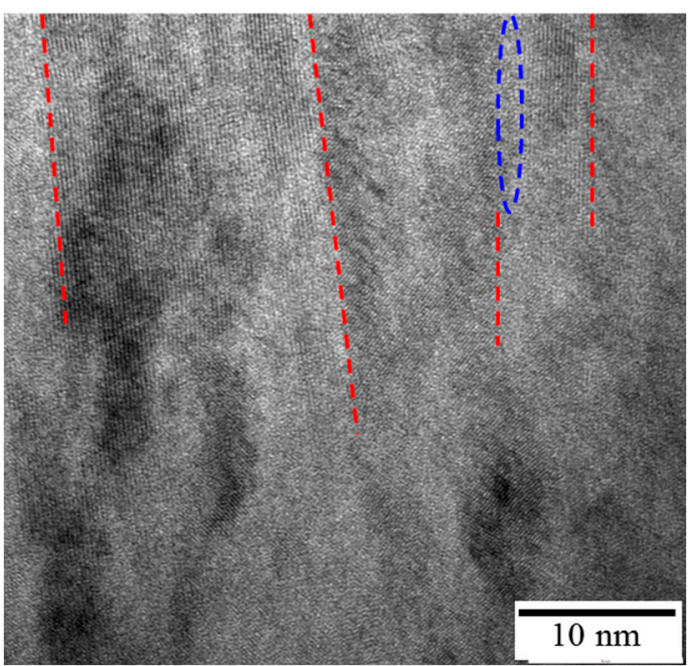

(a)

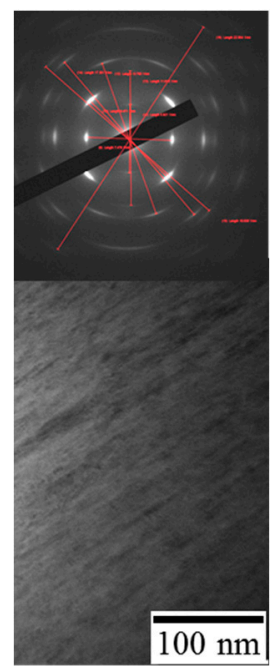

(b)

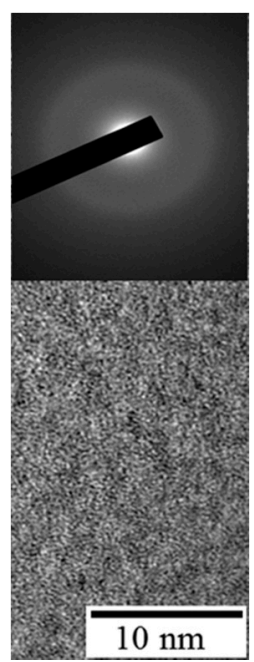

(c)

Figure 5. Cross-section TEM images and SAED patterns for Coatings $1 \mathrm{~A}(\mathbf{a}, \mathbf{b})$ and $2 \mathrm{~N}(\mathbf{c})$. The red dashed lines correspond to the boundaries between columnar grains, and the blue oval shows amorphous region.

Coating 1A featured a columnar structure, with a 5-20 nm diameter of individual columnar grains. A similar microstructure was reported for the $\mathrm{ZrB}_{2}$ coatings, deposited on alumina substrate by magnetron sputtering [50]. One can see the conjunctions between the crystal lattices of adjacent grains in the microstructure (Figure 5a). Additionally, 
isolated amorphous areas are present between the crystallites. The measurements of the interplanar distance via HRTEM and SAED produced the following values: $0.3393,0.2675$, $0.2098,0.1718,0.1546,0.1422,0.1337,0.1252$, and $0.1143 \mathrm{~nm}$, which correspond to the hexagonal $\mathrm{h}-\mathrm{ZrB}_{2}$. Other elements in the coating (Mo and $\mathrm{Si}$ ) form an amorphous phase. TEM investigation of Coating $2 \mathrm{~N}$ revealed that its structure is amorphous, which agrees well with the XRD data.

The nanoindentation-derived mechanical properties of the coatings, including hardness, Young's modulus, elastic recovery, and parameters $\mathrm{H} / \mathrm{E}$ and $\mathrm{H}^{3} / \mathrm{E}^{2}$, are provided in Table 1. It should be noted that the $\mathrm{H} / \mathrm{E}$ and $\mathrm{H}^{3} / \mathrm{E}^{2}$ ratios can be used for an assessment of the wear resistance, adhesion to the substrate, and fracture resistance of the coatings, as well as the type of localized deformation [51-53]. The non-reactive-deposited coating (Coating 1A) demonstrated higher hardness $\mathrm{H}=36 \mathrm{GPa}$, Young's modulus $\mathrm{E}=415 \mathrm{GPa}$, elastic recovery $\mathrm{W}=84 \%$, and $\mathrm{H}^{3} / \mathrm{E}^{2}$ ratio $=0.271 \mathrm{GPa}$. The addition of $\mathrm{N}$ led to a decrease in mechanical properties; the hardness of Coating $2 \mathrm{~N}$ was $14 \mathrm{GPa}, \mathrm{E}=160 \mathrm{GPa}, \mathrm{W}=64 \%$. Both Coatings $1 \mathrm{~A}$ and $2 \mathrm{~N}$ were characterized by a $\mathrm{H} / \mathrm{E}$ ratio $=0.09$. A similar decrease in the mechanical properties was demonstrated in $[54,55]$ at $\mathrm{N}$ content $>15$ at $\%$, which may be associated with structural factors, in particular, with an increase in the concentration of the soft amorphous nitrogen-containing phase. The structural characteristics of the main phase determine the mechanical performance of the coatings. Therefore, the formation of hexagonal $\mathrm{h}-\mathrm{ZrB}_{2}$ might affect the coating's mechanical properties because the cubic c-ZrB is harder than $\mathrm{h}-\mathrm{ZrB}_{2}$, but the latter has a higher resistance to elastic-plastic deformation [56].

For the first estimations, the tribological tests were conducted in relatively mild conditions: $1 \mathrm{~N}$ load, $50 \mathrm{~m}$ distance. For Coating 1A, the friction coefficient increased from 0.25 to 0.65 during the first $10 \mathrm{~m}$ distance and then stabilized around $\sim 0.6$ and remained constant until the end of the test. The nitrogen-containing coating (Coating $2 \mathrm{~N}$ ) had an initial coefficient of friction similar to Coating 1A. During the test, the coefficient of friction gradually increased and reached $\sim 1.0$ at a $50 \mathrm{~m}$ distance.

The analysis of the wear tracks revealed that Coating $1 \mathrm{~A}$ successfully resisted wear, and the depth of penetration of the counterbody did not exceed $0.2 \mu \mathrm{m}$. Coating $2 \mathrm{~N}$ experienced more pronounced wear, and the depth of wear track was $1.6 \mu \mathrm{m}$; however, the wear track depth did not exceed the coatings' thickness of $3.7 \mu \mathrm{m}$. The wear rate of Coating 1A was hard to estimate due to the lack of pronounced wear. However, taking into account the surface roughness, we can conclude that the wear rate did not exceed $4.9 \times 10^{-6} \mathrm{~mm}^{3} \mathrm{~N}^{-1} \mathrm{~m}^{-1}$. The profilometry-derived wear rate for Coating $2 \mathrm{~N}$ was $9.0 \times 10^{-5} \mathrm{~mm}^{3} \mathrm{~N}^{-1} \mathrm{~m}^{-1}$. Thus, Coating $1 \mathrm{~A}$ demonstrated considerably higher wear resistance at a $1 \mathrm{~N}$ load and $50 \mathrm{~m}$ distance as compared to Coating $2 \mathrm{~N}$. A similar effect was reported in [55], where the introduction of the nitrogen into the magnetron-sputters $\mathrm{ZrB}_{2}$ coating resulted in a $\sim 15 \%$ increase in the friction coefficient. Therefore, Coating $1 \mathrm{~A}$ displayed a considerably higher wear resistance as compared to Coating $2 \mathrm{~N}$. Interestingly, both Coatings $1 \mathrm{~A}$ and $2 \mathrm{~N}$ were characterized by close values of the $\mathrm{H} / \mathrm{E}$ parameters. Therefore, in our case, the wear resistance correlates better with the hardness and elastic resistance values, as well as with the $\mathrm{H}^{3} / \mathrm{E}^{2}$ ratio, which was higher for Coatings $1 \mathrm{~A}$ (Table 1).

The next tribological characterization was conducted in harsher conditions: $5 \mathrm{~N}$ load and 1000 distance. The results of tribological tests are provided in Figure 6.

Coating $1 \mathrm{~A}$ demonstrated a stable friction coefficient $(0.80-0.88)$ at a $0-1000 \mathrm{~m}$ distance. The friction coefficient for Coating $2 \mathrm{~N}$ increased from 0.14 to 0.83 at a $0-8.3 \mathrm{~m}$ distance. The low friction coefficient in the initial stage might be related to the presence of B-N bonds in the $2 \mathrm{~N}$ coating. A similar effect was previously reported [34] in the investigation of the influence of nitrogen on the properties of boride coatings. After a short distance, the testing was stopped to fixate the moment of the complete wear of the coating.

The analysis of the wear tracks (Figure 7) revealed that Coating 1A successfully resisted wear, and the depth of penetration of the counterbody did not exceed $0.5 \mu \mathrm{m}$. 


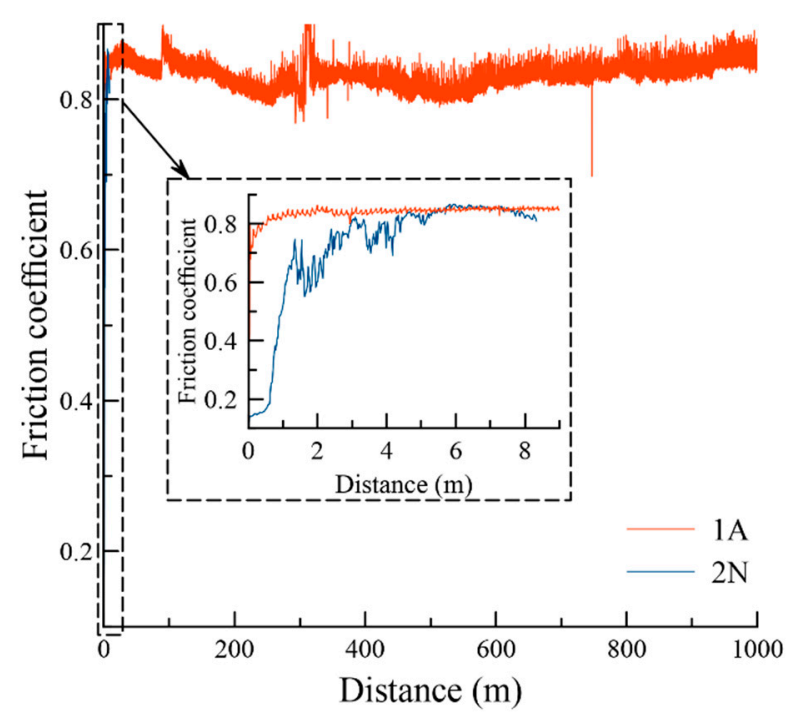

Figure 6. The friction coefficient for Coatings $1 \mathrm{~A}$ and $2 \mathrm{~N}$.
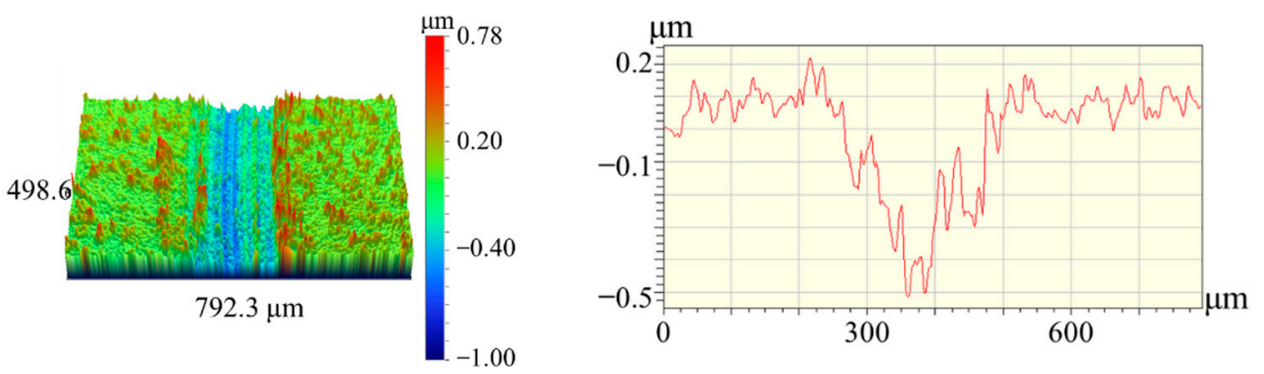

(a)
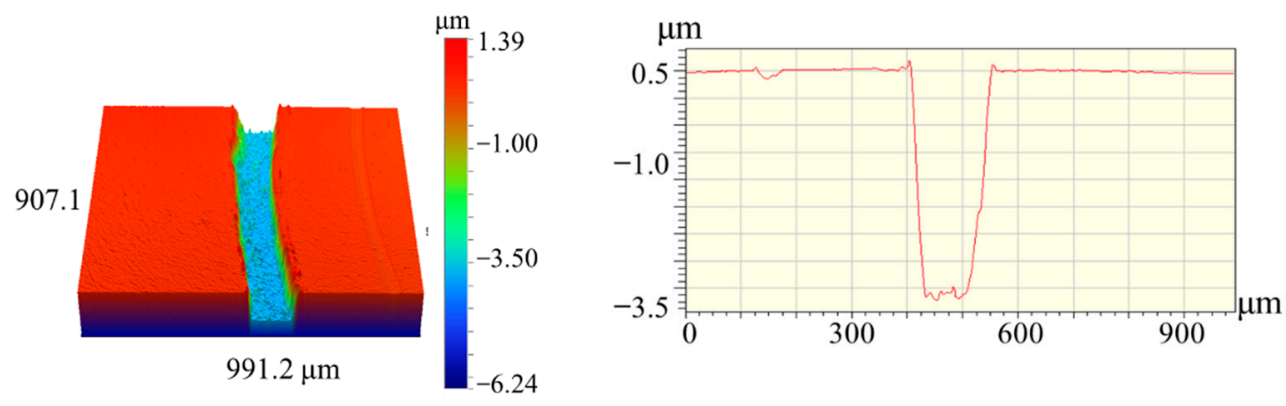

(b)

Figure 7. Three-dimensional (3D) and 2D images of the wear tracks for Coatings 1 (a) and 2 (b).

The wear rate of the $1 \mathrm{~A}$ coating was $4.2 \times 10^{-7} \mathrm{~mm}^{3} \mathrm{~N}^{-1} \mathrm{~m}^{-1}$. Importantly, the wear track depth of the nonreactive coating was $0.4 \mu \mathrm{m}$, which did not exceed the total coating's thickness of $5 \mu \mathrm{m}$. Coating $2 \mathrm{~N}$ experienced complete wear during the test, and the wear track depth was $\sim 4 \mu \mathrm{m}$ at the coating's thickness of $3.7 \mu \mathrm{m}$.

Therefore, in our case, the wear resistance correlates better with the hardness and elastic resistance values, as well as with the $\mathrm{H}^{3} / \mathrm{E}^{2}$ ratio, which was higher for Coating $1 \mathrm{~A}$ (Table 1). Notably, our previously investigated coatings $\mathrm{ZrB}_{2}$ and $\mathrm{Zr}-\mathrm{B}-\mathrm{N}$ demonstrated specific wear rates of $1.3 \div 8.2 \times 10^{-6} \mathrm{~mm}^{3} /(\mathrm{Nm})$, correspondingly [57], which is an order of magnitude higher than the wear rate of the $1 \mathrm{~A}$ coating (Zr-Mo-Si-B). Specimen $1 \mathrm{~A}$ was also characterized by higher wear resistance as compared to the baseline $\mathrm{ZrB}_{2}$ coating $\left(2.8 \times 10^{-6} \mathrm{~mm}^{3} /(\mathrm{Nm})\right)[55]$. 
Single-step isothermal annealing runs at $1000{ }^{\circ} \mathrm{C}$ with consecutive weight measurements revealed an increase in the mass of the first coating for $1.1 \mu \mathrm{g} / \mathrm{cm}^{2}$ after one run, whereas Coating $2 \mathrm{~N}$ demonstrated a drop in mass $12 \mu \mathrm{g} / \mathrm{cm}^{2}$. The mass gain of Coating $1 \mathrm{~A}$ is evidently caused by the formation of an oxide layer, whereas the mass decrease of Coating $2 \mathrm{~N}$ might be related to the evaporation of the nonmetallic species (predominantly nitrogen) after reaction with oxygen. The SEM and EDS data of the oxidized coatings are presented in Figures 8 and 9.

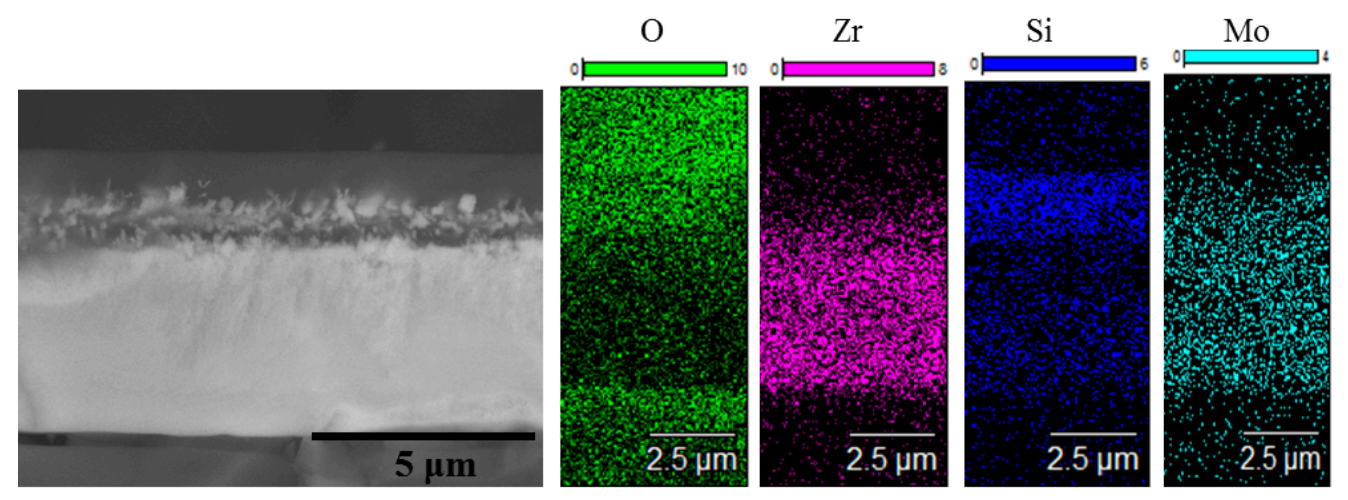

Figure 8. Cross-section SEM images of the Zr-Mo-Si-B coating (Coating 1A) after air annealing at $1000{ }^{\circ} \mathrm{C}$ for $1 \mathrm{~h}$. The figure illustrates protection from oxidation.
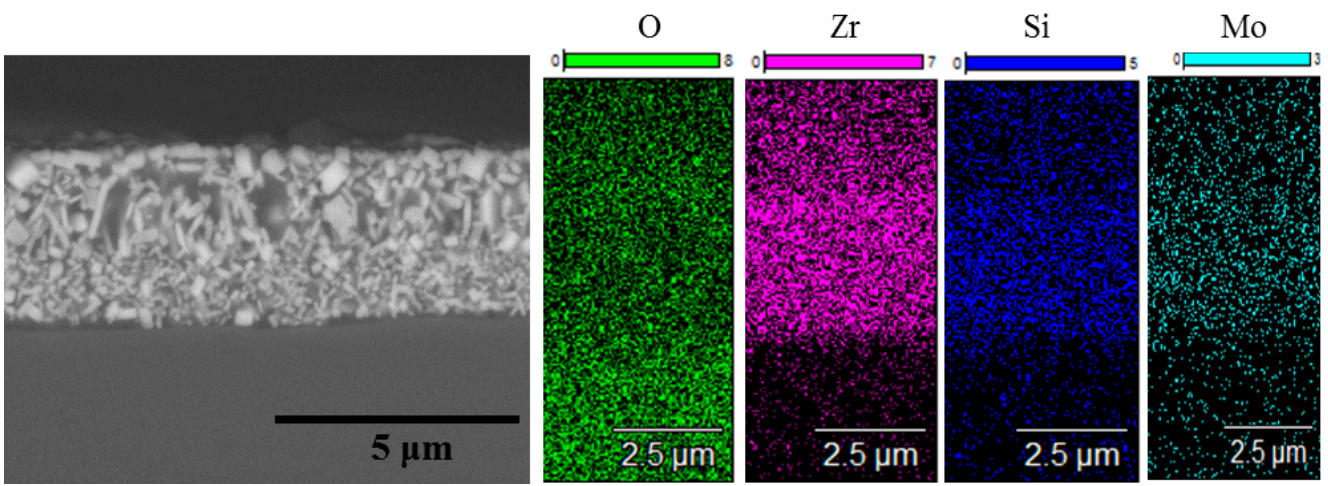

Figure 9. Cross-section SEM images of the Zr-Mo-Si-B-N coating (Coating 2N) after air annealing at $1000{ }^{\circ} \mathrm{C}$ for $1 \mathrm{~h}$. The figure illustrates complete oxidation.

On the surface of Coating 1A, a three-layer oxide film formed, consisting of an upper $0.9 \mu \mathrm{m}$ wide amorphous silica layer, followed by a lower layer consisting mostly of $450-700 \mathrm{~nm}$ zirconia crystallites in the silica matrix and the lowest layer of silica adjacent to the $3.2 \mu \mathrm{m}$ thick nonoxidized part of the coating. Coating $2 \mathrm{~N}$ after annealing in the same regime experienced complete oxidation and formed a single layer of polydisperse zirconia crystallites (bright spots in the microstructure) in the amorphous silica matrix (dark spots in the microstructure).

The XRD patterns of the Coatings $1 \mathrm{~A}$ and $2 \mathrm{~N}$ after annealing in air at $1000{ }^{\circ} \mathrm{C}$ are provided in Figure 10.

The annealing in air resulted in the formation of an oxide layer on the surface of Coating 1A. According to the XRD data, the layer was comprised of monoclinic $\mathrm{m}-\mathrm{MoO}_{2}$ (JCPDS 76-1807), hexagonal h- $\mathrm{MoO}_{3}$ (JCPDS 65-0033), monoclinic $\mathrm{m}-\mathrm{ZrO}_{2}$ (JCPDS 650728), and tetragonal $\mathrm{t}-\mathrm{ZrO}_{2}$ (JCPDS 68-0200). Additionally, low-intensity peaks of the phase $\mathrm{Al}_{4} \mathrm{Si}_{1} \mathrm{O}_{10}$ (JCPDS 74-4144) were observed. This phase was formed as a result of interaction between the silicon and substrate on the boundary between substrate and coating. For Coating $1 \mathrm{~A}, \mathrm{~h}-\mathrm{ZrB}_{2}$ peaks were observed (JCPDS 89-3930) at $2 \Theta=25.7,32.6$, 52.8 , and $65.5^{\circ}$, signalizing the retention of the coating during the annealing. Coating $2 \mathrm{~N}$ contained similar oxide phases $\mathrm{m}-\mathrm{MoO}_{2}, \mathrm{~h}-\mathrm{MoO}_{3}, \mathrm{~m}-\mathrm{ZrO} 2, \mathrm{t}-\mathrm{ZrO}_{2}$, and $\mathrm{Al}_{4} \mathrm{Si}_{1} \mathrm{O}_{10}$. The $\mathrm{ZrN}$ peak, which was present in the as-deposited coating, was not found after the 
annealing. The lack of phases characteristic for the as-deposited coating signifies complete oxidation of the $2 \mathrm{~N}$ specimen, which is supported by the SEM investigation. The weight changes for Coatings $1 \mathrm{~A}$ and $2 \mathrm{~N}$ upon oxidation (Figure 11) were monitored in a step-wise manner after annealing runs in the air in the $200-1000{ }^{\circ} \mathrm{C}$ interval with $200{ }^{\circ} \mathrm{C}$ increments and dwelling time of $30 \mathrm{~min}$. Up to a temperature of $600{ }^{\circ} \mathrm{C}$ inclusive, the behavior of Coatings $1 \mathrm{~A}$ and $2 \mathrm{~N}$ does not differ significantly. There is a slight decrease in the mass of the samples. The mass losses derived by approximation of the curves were 0.0013 and $0.0016 \mathrm{mg} / \mathrm{min}$ for the Coatings 1A and 2N, correspondingly. In the case of Sample 1A, the sharp increase in mass at temperatures of $600-1000{ }^{\circ} \mathrm{C}$ is probably due to the formation of $\mathrm{SiO}_{2}$ and $\mathrm{ZrO}_{2}$ oxide layers. The mass gain rate of the $1 \mathrm{~A}$ sample in this temperature interval was $0.0067 \mathrm{mg} / \mathrm{min}$.

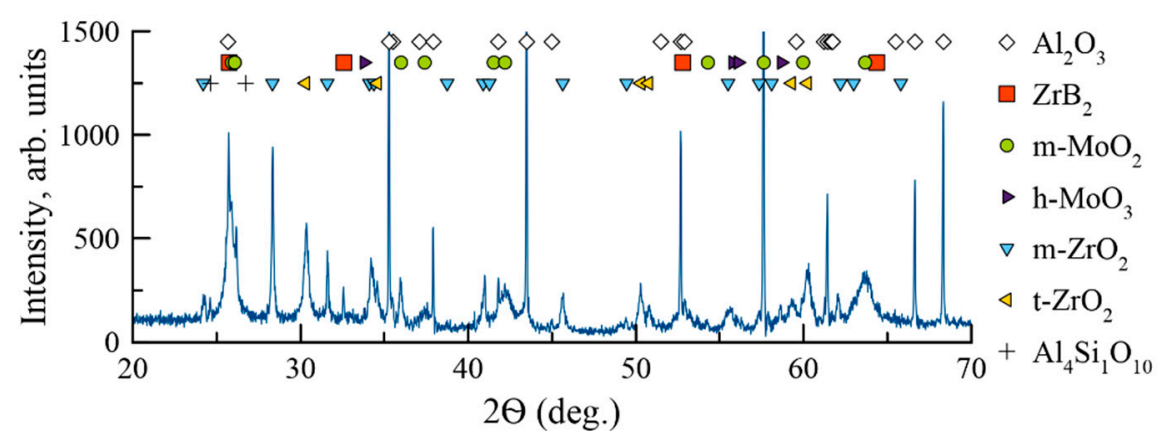

(a)

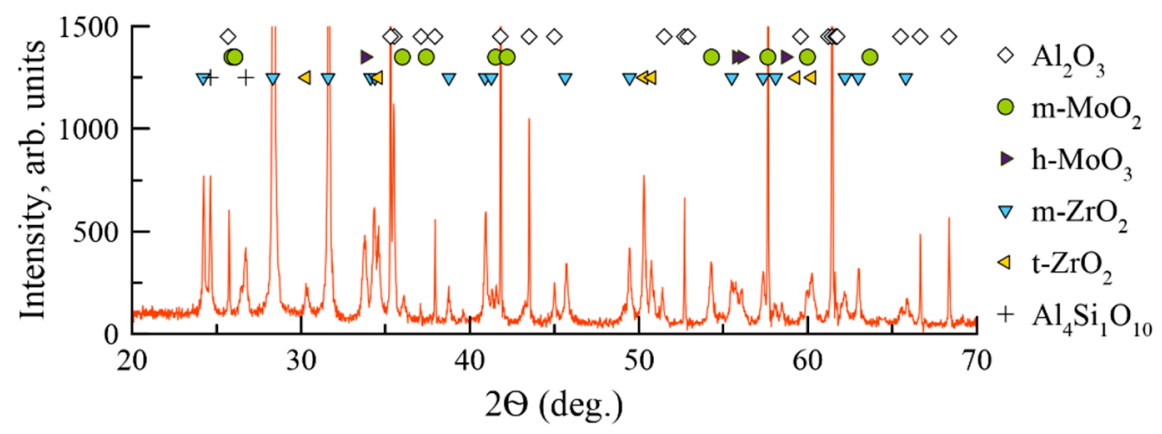

(b)

Figure 10. XRD patterns of Coatings $1 \mathrm{~A}(\mathbf{a})$ and $2 \mathrm{~N}(\mathbf{b})$ after annealing in air at $1000^{\circ} \mathrm{C}$.

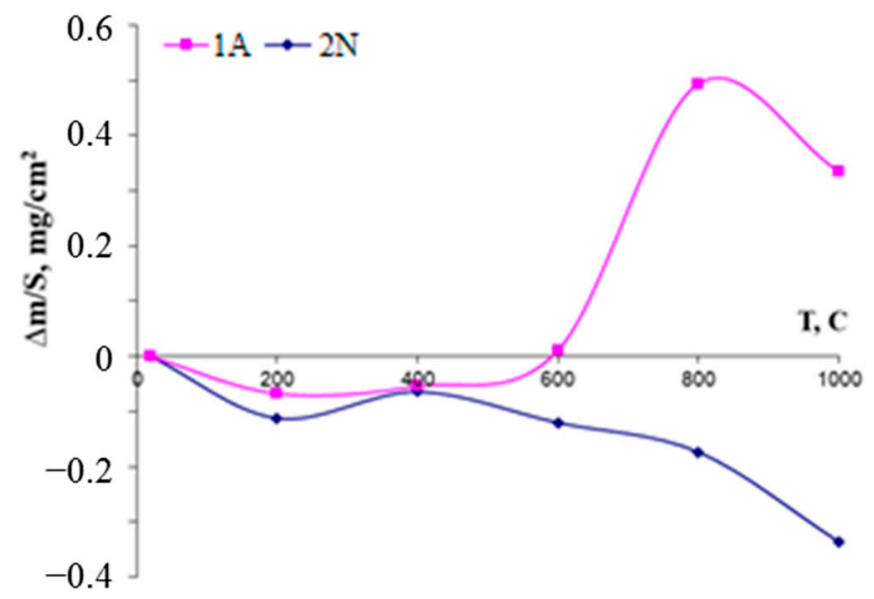

Figure 11. Weight changes of Coatings $1 \mathrm{~A}$ and $2 \mathrm{~N}$ in relation to the annealing temperature.

On the other hand, the mass loss for sample $2 \mathrm{~N}$ is due to the high losses of nitrogen atoms due to the volatilization of nitrogen oxide gas. In the $600-1000{ }^{\circ} \mathrm{C}$, interval 
the mass decrease rate of the nitrogen-containing coating increased considerably, up to $0.004 \mathrm{mg} / \mathrm{min}$. In comparison, the oxidation rate of $\mathrm{Zr}-\mathrm{Si}-\mathrm{B}$ coatings in similar conditions was $\sim 0.01 \mathrm{mg} / \mathrm{min}[32]$.

To ascertain the peak oxidation resistance of the developed coatings, additional oxidation runs were performed using $10 \mathrm{~min}$ non-isothermal dwelling times (heating and cooling with a Nabertherm LHT $01 / 17$ furnace at $10^{\circ} / \mathrm{min}$ ) at 1300,1400 and $1500{ }^{\circ} \mathrm{C}$ revealed that both Coatings $1 \mathrm{~A}$ and $2 \mathrm{~N}$ after annealing become optically transparent due to the complete oxidation and formation of a continuous oxide layer on top of the alumina substrate. Coating 1A was able to withstand a short-term isothermal oxidation run (10 min, $1200{ }^{\circ} \mathrm{C}$, SNOL furnace) without complete oxidation. The results of the investigation of Coating $1 \mathrm{~A}$ after this run are provided in Figure 12.

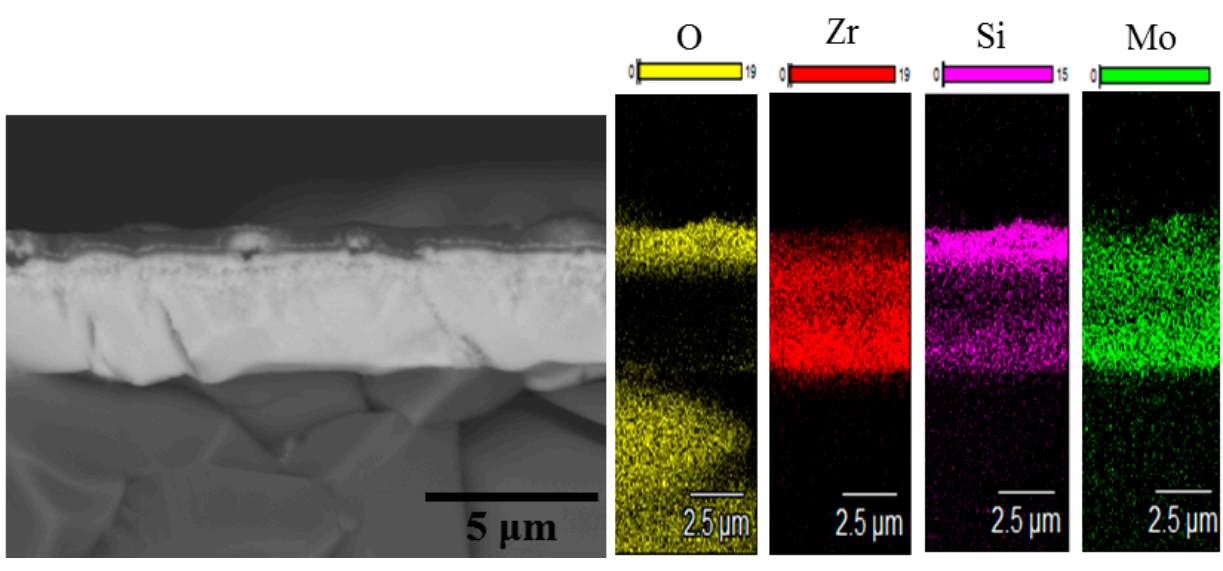

Figure 12. SEM data for the Zr-Mo-Si-B coating after exposition at $1200{ }^{\circ} \mathrm{C}$ for $10 \mathrm{~min}$.

One can see that the coating contains a nonoxidized layer. The oxide layer formed at $1200{ }^{\circ} \mathrm{C}$ is structurally similar to the oxide layers formed at $1000{ }^{\circ} \mathrm{C}$.

The baseline coating $\mathrm{ZrB}_{2}$ demonstrated low oxidation resistance: complete oxidation occurred upon heating in the air up to $700{ }^{\circ} \mathrm{C}$ for $1 \mathrm{~h}$ [8]. Coating $1 \mathrm{~A}$, deposited in this work, retained its protective properties up to $120{ }^{\circ} \mathrm{C}$. Therefore, the introduction of $\mathrm{MoSi}_{2}$ into the coating resulted in a massive increase in the oxidation resistance without any notable deterioration of the mechanical performance. The hardness of the $\mathrm{ZrB}_{2}$ coating and 1A specimen (Zr-Mo-Si-B) produced and investigated in similar conditions was 36-37 GPa. In comparison, our previously investigated ternary coatings $\mathrm{Zr}-\mathrm{Si}-\mathrm{B}$ and Mo-Si-B displayed higher oxidation resistance up to $1500-1700{ }^{\circ} \mathrm{C}[8,26]$, but their mechanical properties were more modest $(\mathrm{H}=22-27 \mathrm{GPa})$.

\section{Conclusions}

Zr-Mo-Si-B coatings were deposited by magnetron sputtering in Ar and $\mathrm{N}_{2}$ using direct current. Two types of coatings with a thickness of 3.7-5.0 $\mu \mathrm{m}$ were deposited. The coatings deposited in Ar were mainly composed of hexagonal h- $\mathrm{ZrB}_{2}$ with crystallite sizes below $50 \mathrm{~nm}$, whereas the coatings deposited in nitrogen were X-ray amorphous. The coatings deposited in Ar demonstrated superior mechanical, tribological, and chemical properties, with a hardness of $36 \mathrm{GPa}$, elastic recovery of $84 \%, \mathrm{H}^{3} / \mathrm{E}^{2}$ ratio $=0.271 \mathrm{GPa}$, wear rate of $4.2 \times 10^{-7} \mathrm{~mm}^{3} \mathrm{~N}^{-1} \mathrm{~m}^{-1}$, and oxidation resistance up to $1200{ }^{\circ} \mathrm{C}$. The notable oxidation resistance of the $\mathrm{Zr}-\mathrm{Mo}-\mathrm{Si}-\mathrm{B}$ coatings results from the formation of a protective surface layer consisting of an amorphous silica matrix with dispersed zirconia nanocrystallites (100-350 nm), which can efficiently impede the diffusion of oxygen into the unreacted coating.

Author Contributions: Conceptualization, deposition, annealing, writing and editing: P.K.-K.; Triboinvestigation, profilometry, analysis, calculations, writing and investigation: A.S.; editing: S.V.; 
investigation: Y.P., P.L., and A.O. Conceptualization and editing: E.L. All authors have read and agreed to the published version of the manuscript.

Funding: This work was carried out with financial support from the Ministry of Science and Higher Education of the Russian Federation (Project No. 0718-2020-0034 of State Assignment).

Institutional Review Board Statement: Not applicable.

Informed Consent Statement: Not applicable.

Data Availability Statement: The data presented in this study are available on request from the corresponding author.

Acknowledgments: The authors are grateful to N.V. Shvindina and M.I. Petrzhik for assistance in the microstructural studies and nanoindentation, respectively.

Conflicts of Interest: The authors declare no conflict of interest.

\section{References}

1. Sonber, J.K.; Murthy, T.S.R.C.; Subramanian, C.; Kumar, S.; Fotedar, R.K.; Suri, A.K. Investigations on synthesis of ZrB 2 and development of new composites with $\mathrm{HfB}_{2}$ and TiSi 2 . Int. J. Refract. Met. Hard Mater. 2011, 29, 21-30. [CrossRef]

2. Saunders, T.; Grasso, S.; Reece, M.J. Limiting oxidation of $\mathrm{ZrB}_{2}$ by application of an electric field across its oxide scale. J. Alloys Compd. 2015, 653, 629-635. [CrossRef]

3. Wang, T.G.; Liu, Y.; Zhang, T.; Kim, D.I.; Kim, K.H. Influence of Nitrogen Flow Ratio on the Microstructure, Composition, and Mechanical Properties of DC Magnetron Sputtered Zr-B-O-N Films. J. Mater. Sci. Technol. 2012, 28, 981-991. [CrossRef]

4. Macías, H.A.; Yate, L.; Coy, L.E.; Aperador, W.; Olaya, J.J. Influence of Si-addition on wear and oxidation resistance of TiWSixN thin films. Ceram. Int. 2019, 45, 17363-17375. [CrossRef]

5. Kiryukhantsev-Korneev, P.V.; Andreev, S.O.; Shvyndina, N.V.; Levashov, E.A.; Timofeev, A.N.; Shtansky, D.V. The influence of Si concentrations on the oxidation resistance of Mo-Si-B-(N) coatings. Russ. J. Non-Ferrous Met. 2014, 55, 645-651. [CrossRef]

6. Xin, L.; Chen, Q.; Teng, Y.; Wang, W.; Sun, A.; Zhu, S.; Wang, F. Effects of silicon and multilayer structure of TiAl(Si)N coatings on the oxidation resistance of Ti6Al4V. Surf. Coat. Technol. 2013, 228, 48-58. [CrossRef]

7. $\quad$ Bae, K.E.; Chae, K.W.; Park, J.K.; Lee, W.S.; Baik, Y.J. Oxidation behavior of amorphous boron carbide-silicon carbide nanomultilayer thin films. Surf. Coat. Technol. 2015, 276, 55-58. [CrossRef]

8. Kiryukhantsev-Korneev, F.V.; Lemesheva, M.V.; Shvyndina, N.V.; Levashov, E.A.; Potanin, A.Y. Structure, Mechanical Properties, and Oxidation Resistance of $\mathrm{ZrB}_{2}, \mathrm{ZrSiB}$, and $\mathrm{ZrSiB} / \mathrm{SiBC}$ Coatings. Prot. Met. Phys. Chem. Surf. 2018, 54, 1147-1156. [CrossRef]

9. Ren, X.; Li, H.; Chu, Y.; Li, K.; Fu, Q. ZrB $2-S i C$ gradient oxidation protective coating for carbon/carbon composites. Ceram. Int. 2014, 40, 7171-7176. [CrossRef]

10. Ren, Y.; Qian, Y.; Xu, J.; Zuo, J.; Li, M. Ultra-high temperature oxidation resistance of $\mathrm{ZrB}_{2}-20 \mathrm{SiC}$ coating with TaSi2 addition on siliconized graphite. Ceram. Int. 2019, 45, 15366-15374. [CrossRef]

11. Yang, X.; Feng, C.; Qing, W. $\mathrm{ZrB}_{2}-\mathrm{SiC}$ as a protective coating for $\mathrm{C} / \mathrm{SiC}$ composites: Effect of high temperature oxidation on thermal shock property and protection mechanism. J. Asian Ceram. Soc. 2016, 4, 159-163. [CrossRef]

12. Aliasgarian, R.; Naderi, M.; Mirsalehi, S.E. Ablation mechanism of $\mathrm{ZrB}_{2}$-SiC coating for SiC-coated graphite under an oxyacetylene flame. Surf. Coat. Technol. 2018, 350, 511-518. [CrossRef]

13. Feng, X.; Wang, X.; Liu, Y.; Guo, Y.; Zhang, M.; Zhang, L.; Jian, X.; Yin, L.; Xie, J.; Deng, L. Oxidation behaviour of plasma-sprayed $\mathrm{ZrB}_{2}$-SiC coatings. Ceram. Int. 2019, 45, 2385-2392. [CrossRef]

14. Krishnarao, R.V.; Alam, M.Z.; Das, D.K. In-situ formation of SiC, $\mathrm{ZrB}_{2}-\mathrm{SiC}$ and $\mathrm{ZrB}_{2}-\mathrm{SiC}-\mathrm{B}_{4} \mathrm{C}-\mathrm{YAG}$ coatings for high temperature oxidation protection of C/C composites. Corros. Sci. 2018, 141, 72-80. [CrossRef]

15. $\mathrm{Hu}, \mathrm{D}$.; Fu, Q.; Liu, T.; Tong, M. Structural design and ablation performance of $\mathrm{ZrB}_{2} / \mathrm{MoSi}_{2}$ laminated coating for SiC coated carbon/carbon composites. J. Eur. Ceram. Soc. 2020, 40, 212-219. [CrossRef]

16. Liu, X.; Deng, C.; Deng, C.; Liu, M.; Zhou, K. Mullite-modified ZrB $2-\mathrm{MoSi}_{2}$ coating for carbon/carbon composites to withstand long term ablation. Ceram. Int. 2018, 44, 4330-4337. [CrossRef]

17. Yanjiao, Y.; Mingjiang, D.; Chunbei, W.; Huijun, H.; Songsheng, L. Microstructure and Anti-oxidation Properties of SiC/MoSi ${ }_{2}-$ $\mathrm{ZrB}_{2}$ Coating for Carbon/Carbon Composites Prepared by Magnetron Sputtering Method. Rare Met. Mater. Eng. 2017, 46, 3663-3668. [CrossRef]

18. Jinyuan, M.; Min, L.; Chunming, D.; Jie, M.; Dechang, Z. A Comparative Study of Spray-dried and Mechanically-mixed $\mathrm{ZrB}_{2}-\mathrm{MoSi}_{2}$ Composite Coatings Fabricated by Low Pressure Plasma Spray. Rare Met. Mater. Eng. 2016, 45, 1386-1390. [CrossRef]

19. Cheng, S.; Geng, L.; Liu, X.; Wang, Y. Laser ablation behavior and mechanism of C/SiC coated with $\mathrm{ZrB}_{2}-\mathrm{MoSi}_{2}-\mathrm{SiC}_{\mathrm{C}} \mathrm{Mo}$ prepared by HVOF. Ceram. Int. 2020, 46, 17752-17762. [CrossRef]

20. Niu, Y.; Wang, H.; Li, H.; Zheng, X.; Ding, C. Dense $\mathrm{ZrB}_{2}-\mathrm{MoSi}_{2}$ composite coating fabricated by low pressure plasma spray (LPPS). Ceram. Int. 2013, 39, 9773-9777. [CrossRef]

21. Wang, Z.; Niu, Y.; Hu, C.; Li, H.; Zeng, Y.; Zheng, X.; Ren, M.; Sun, J. High temperature oxidation resistance of metal silicide incorporated $\mathrm{ZrB}_{2}$ composite coatings prepared by vacuum plasma spray. Ceram. Int. 2015, 41, 14868-14875. [CrossRef] 
22. Niu, Y.; Wang, H.; Liu, Z.; Hu, C.; Wang, X.; Zheng, X.; Ding, C. Microstructure evolution of ZrB ${ }_{2}-\mathrm{MoSi}_{2}$ composite coatings at middle and high temperatures. Surf. Coat. Technol. 2015, 273, 30-38. [CrossRef]

23. Yang, T.; Guo, X. Oxidation behavior of Zr-Y alloyed Mo-Si-B based alloys. Int. J. Refract. Met. Hard Mater. 2020, 88, 105200. [CrossRef]

24. Wang, J.; Li, B.; Li, R.; Chen, X.; Wang, T.; Zhang, G. Unprecedented oxidation resistance at $900{ }^{\circ} \mathrm{C}$ of Mo-Si-B composite with addition of ZrB2. Ceram. Int. 2020, 46, 14632-14639. [CrossRef]

25. Kiryukhantsev-Korneev, P.V.; Iatsyuk, I.V.; Shvindina, N.V.; Levashov, E.A.; Shtansky, D.V. Comparative investigation of structure, mechanical properties, and oxidation resistance of Mo-Si-B and Mo-Al-Si-B coatings. Corros. Sci. 2017, 123, 319-327. [CrossRef]

26. Sossaman, T.; Perepezko, J.H. Viscosity control of borosilica by Fe doping in Mo-Si-B environmentally resistant alloys. Corros. Sci. 2015, 98, 406-416. [CrossRef]

27. Dong, Z.H.; Peng, X.; Wang, F.H. Oxidation of a $\mathrm{ZrB}_{2}$ coating fabricated on Ta-W alloy by electrophoretic deposition and laser melting. Mater. Lett. 2015, 148, 76-78. [CrossRef]

28. Gu, S.-c.; Zhu, S.-z.; Ma, Z.; Han, S.-p.; Liu, Y.-b. Preparation and properties of $\mathrm{ZrB}_{2}-\mathrm{MoSi}_{2}$-glass composite powders for plasma sprayed high temperature oxidation resistance coating on C/SiC composites. Powder Technol. 2019, 345, 544-552. [CrossRef]

29. Jiang, Y.; Feng, D.; Ru, H.; Wang, W.; Zhang, C. Oxidation protective $\mathrm{ZrB}_{2}-\mathrm{MoSi}_{2}-\mathrm{SiC}-\mathrm{Si}$ coating for graphite materials prepared by slurry dipping and vapor silicon infiltration. Surf. Coat. Technol. 2018, 339, 91-100. [CrossRef]

30. Lange, A.; Braun, R. Magnetron-sputtered oxidation protection coatings for Mo-Si-B alloys. Corros. Sci. 2014, 84, 74-84. [CrossRef]

31. Riedl, H.; Vieweg, A.; Limbeck, A.; Kalaš, J.; Arndt, M.; Polcik, P.; Euchner, H.; Bartosik, M.; Mayrhofer, P.H. Thermal stability and mechanical properties of boron enhanced Mo-Si coatings. Surf. Coat. Technol. 2015, 280, 282-290. [CrossRef]

32. Kiryukhantsev-Korneev, F.V.; Yatsyuk, I.V. Study of $\mathrm{ZrSiB}$ Coatings Obtained by Magnetron Sputtering of $\mathrm{ZrB}{ }_{2}-20 \% \mathrm{Si}$ and ZrB2-50\%ZrSi2 Cathodes. Phys. At. Nucl. 2019, 82, 1437-1440. [CrossRef]

33. Kiryukhantsev-Korneev, F.V.; Novikov, A.V.; Sagalova, T.B.; Petrzhik, M.I.; Levashov, E.A.; Shtansky, D.V. A comparative study of microstructure, oxidation resistance, mechanical, and tribological properties of coatings in Mo-B- $(\mathrm{N}), \mathrm{Cr}-\mathrm{B}-(\mathrm{N})$ and Ti-B- $(\mathrm{N})$ systems. Phys. Met. Metallogr. 2017, 118, 1136-1146. [CrossRef]

34. Kiryukhantsev-Korneev, P.V.; Pierson, J.F.; Bychkova, M.Y.; Manakova, O.S.; Levashov, E.A.; Shtansky, D.V. Comparative Study of Sliding, Scratching, and Impact-Loading Behavior of Hard CrB2 and Cr-B-N Films. Tribol. Lett. 2016, 63, 1-11. [CrossRef]

35. Shtansky, D.V.; Sheveyko, A.N.; Sorokin, D.I.; Lev, L.C.; Mavrin, B.N.; Kiryukhantsev-Korneev, P.V. Structure and properties of multi-component and multilayer TiCrBN/WSex coatings deposited by sputtering of TiCrB and WSe 2 targets. Surf. Coat. Technol. 2008, 202, 5953-5961. [CrossRef]

36. Kiryukhantsev-Korneev, F.V. Possibilities of glow discharge optical emission spectroscopy in the investigation of coatings. Russ. J. Non-Ferrous Met. 2014, 55, 494-504. [CrossRef]

37. Levashov, E.A.; Shtansky, D.V.; Kiryukhantsev-Korneev, P.V.; Petrzhik, M.I.; Tyurina, M.Y.; Sheveiko, A.N. Multifunctional nanostructured coatings: Formation, structure, and the uniformity of measuring their mechanical and tribological properties Russ. Metall. 2010, 2010, 917-935. [CrossRef]

38. Tengdelius, L.; Samuelsson, M.; Jensen, J.; Lu, J.; Hultman, L.; Forsberg, U.; Janzén, E.; Högberg, H. Direct current magnetron sputtered $\mathrm{ZrB}_{2}$ thin films on $4 \mathrm{H}-\mathrm{SiC}(0001)$ and $\mathrm{Si}(100)$. Thin Solid Films 2014, 550, 285-290. [CrossRef]

39. Zhang, M.; Yang, G.; Zhang, L.; Zhang, Y.; Yin, J.; Ma, X.; Wen, J.; Dai, L.; Wang, X.; Chen, H.; et al. Application of ZrB 2 thin film as a low emissivity film at high temperature. Appl. Surf. Sci. 2020, 527, 146763. [CrossRef]

40. Samuelsson, M.; Jensen, J.; Helmersson, U.; Hultman, L.; Högberg, H. ZrB 2 thin films grown by high power impulse magnetron sputtering from a compound target. Thin Solid Films 2012, 526, 163-167. [CrossRef]

41. Kiryukhantsev-Korneev, P.V.; Pierson, J.F.; Kuptsov, K.A.; Shtansky, D.V. Hard Cr-Al-Si-B-(N) coatings deposited by reactive and non-reactive magnetron sputtering of CrAlSiB target. Appl. Surf. Sci. 2014, 314, 104-111. [CrossRef]

42. Forniés, E.; Escobar Galindo, R.; Sánchez, O.; Albella, J.M. Growth of CrNx films by DC reactive magnetron sputtering at constant $\mathrm{N}_{2}$ /Ar gas flow. Surf. Coat. Technol. 2006, 200, 6047-6053. [CrossRef]

43. Mendizabal, L.; Bayón, R.; G-Berasategui, E.; Barriga, J.; Gonzalez, J.J. Effect of $\mathrm{N}_{2}$ flow rate on the microstructure and electrochemical behavior of TaNx films deposited by modulated pulsed power magnetron sputtering. Thin Solid Films 2016, 610, 1-9. [CrossRef]

44. Bujak, J.; Walkowicz, J.; Kusiński, J. Influence of the nitrogen pressure on the structure and properties of (Ti,Al)N coatings deposited by cathodic vacuum arc PVD process. Surf. Coat. Technol. 2004, 180-181, 150-157. [CrossRef]

45. Kuznetsova, T.; Lapitskaya, V.; Khabarava, A.; Chizhik, S.; Warcholinski, B.; Gilewicz, A. The influence of nitrogen on the morphology of ZrN coatings deposited by magnetron sputtering. Appl. Surf. Sci. 2020, 522, 146508. [CrossRef]

46. Houska, J.; Mares, P.; Simova, V.; Zuzjakova, S.; Cerstvy, R.; Vlcek, J. Dependence of characteristics of MSiBCN (M=Ti, Zr, Hf) on the choice of metal element: Experimental and ab-initio study. Thin Solid Films 2016, 616, 359-365. [CrossRef]

47. Houska, J.; Kohout, J.; Vlcek, J. Effect of N and Zr content on structure, electronic structure and properties of ZrBCN materials: An ab-initio study. Thin Solid Films 2013, 542, 225-231. [CrossRef]

48. Pleva, M.; Grančič, B.; Mikula, M.; Truchlý, M.; Roch, T.; Satrapinskyy, L.; Gregor, M.; Ďurina, P.; Girman, V.; Švec, P.; et al. Thermal stability of amorphous Ti-B-Si-N coatings with variable Si/B concentration ratio. Surf. Coat. Technol. 2018, 333, 52-60. [CrossRef] 
49. Lin, J.; Moore, J.J.; Mishra, B.; Pinkas, M.; Sproul, W.D. The structure and mechanical and tribological properties of TiBCN nanocomposite coatings. Acta Mater. 2010, 58, 1554-1564. [CrossRef]

50. Tengdelius, L.; Broitman, E.; Lu, J.; Eriksson, F.; Birch, J.; Nyberg, T.; Hultman, L.; Högberg, H. Hard and elastic epitaxial ZrB 2 thin films on $\mathrm{Al}_{2} \mathrm{O}_{3}$ substrates deposited by magnetron sputtering from a $\mathrm{ZrB}_{2}$ compound target. Acta Mater. 2016, 111, 166-172. [CrossRef]

51. Leyland, A.; Matthews, A. On the significance of the H/E ratio in wear control: A nanocomposite coating approach to optimised tribological behaviour. Wearing 2000, 246, 1-11. [CrossRef]

52. Li, H.; Li, J.; Liu, Z.; Huang, J.; Kong, J.; Xiong, D. Mechanical and tribological properties of $\mathrm{Hf}_{1-\mathrm{x}} \mathrm{Mo}_{\mathrm{x}} \mathrm{N}_{\mathrm{y}}$ thin films as a function of Mo contents. Surf. Coat. Technol. 2019, 375, 589-599. [CrossRef]

53. Levashov, E.A.; Petrzhik, M.I.; Shtansky, D.V.; Kiryukhantsev-Korneev, P.V.; Sheveyko, A.N.; Valiev, R.Z.; Gunderov, D.V.; Prokoshkin, S.D.; Korotitskiy, A.V.; Smolin, A.Y. Nanostructured titanium alloys and multicomponent bioactive films: Mechanical behavior at indentation. Mater. Sci. Eng. A 2013, 570, 51-62. [CrossRef]

54. Wang, J.; Munroe, P.; Zhou, Z.; Xie, Z. Nanostructured molybdenum nitride-based coatings: Effect of nitrogen concentration on microstructure and mechanical properties. Thin Solid Films 2019, 682, 82-92. [CrossRef]

55. Dong, Y.; Wang, T.G.; Yan, B.; Qi, H.J.; Guo, Y.Y.; Xu, S.S. Study on the microstructure and mechanical properties of Zr-B-(N) tool coatings prepared by hybrid coating system. Procedia Manuf. 2018, 26, 806-817. [CrossRef]

56. Li, H.; Zhang, L.; Zeng, Q.; Wang, J.; Cheng, L.; Ren, H.; Guan, K. Crystal structure and elastic properties of ZrB compared with $\mathrm{ZrB}_{2}$ : A first-principles study. Comput. Mater. Sci. 2010, 49, 814-819. [CrossRef]

57. Kiryukhantsev-Korneev, P.V.; Sytchenko, A.D. The Influence of $\mathrm{H}, \mathrm{W}, \mathrm{H} / \mathrm{E}, \mathrm{H}^{3} / \mathrm{E}^{2}$, Structure and Chemical Composition on the Resistance of Ti-B-(N), Mo-B-(N), Cr-B-(N), and Zr-B-(N) Coatings to Cyclic Impact Loading. Prot. Met. Phys. Chem. Surf. 2020, 56, 1190-1200. [CrossRef] 